\title{
Comparison of the efficiency of proteins contained in lucerne hay and soya-bean meal for sheep
}

\author{
BY H. TAGARI \\ Faculty of Agriculture, Hebrew University, Rehovot, Israel \\ (Received 8 fuly 1968-Accepted 15 Fanuary 1969)
}

1. In four feeding experiments with sheep the utilization of proteins contained in lucerne hay and of those in toasted soya-bean meal (SBM), representing a roughage and concentrate feed respectively, were examined. The ration of one group of animals contained lucerne hay as sole source of digestible protein and that of the other SBM.

2. Measurements of the nitrogen balance showed clearly the superiority of lucerne hay as protein source compared with soya-bean meal; this arose from the greater $\mathrm{N}$ retention found with the lucerne hay ration.

3. The influence of both rations on the metabolic pathways of the proteins was examined by following the changes of concentration of various metabolites in the rumen contents and of blood urea at different intervals after feeding.

4. Concentrations of urea found in the blood of the sheep given lucerne hay were lower than those of the other group, a finding which is in agreement with the results of the balance experiments.

5. The concentrations of $\mathrm{NH}_{3}-\mathrm{N}$ and of amino acids in the rumen liquor were higher in sheep given lucerne hay than in those given SBM. These concentrations appeared to be related to the differences between the soluble non-protein $\mathbf{N}$ contents of the two feeds.

6. The results agree with the finding from in vitro experiments that rumen liquor from sheep receiving lucerne hay promoted greater synthesis of protein than rumen liquor from sheep receiving SBM.

7. Total bacterial activity as measured by the reduction of triphenyltetrazolium chloride (dehydrogenase activity) was much higher in the rumen liquor of sheep given lucerne hay than when SBM was given.

8. The concentrations of volatile fatty acids $\left(\mathrm{C}_{2}-\mathrm{C}_{6}\right)$ were much higher in the rumen liquor in sheep on the lucerne hay diet than in those on the SBM diet. After meals of the lucerne hay diet, the concentrations of acids higher than $\mathbf{C}_{2}$, particularly those of valeric acid, exceeded those present in the rumen liquor of the animals kept on the SBM diet.

9. Proline and alanine appeared in relatively higher concentrations in the rumen liquor than the other amino acids determined, and these two acids together with valine disappeared very rapidly. The possible conversion of these amino acids into valeric acid is considered. It is suggested that valeric acid found in relatively high concentrations in rumen liquor of sheep given lucerne hay may be due in part to the deamination of proline, which likewise disappeared very rapidly together with alanine and valine.

It has been shown that the chemical composition and physical properties of the proteins in a feed may considerably affect the efficiency with which they are utilized by ruminants. Furthermore, it has been found that the administration of equal amounts of the same protein with various amounts of different types of carbohydrate affects not only the digestibility and biological value of the proteins (Fontenot, Gallup \& Nelson, 1955; Tagari, Dror, Ascarelli \& Bondi, 1964) but also their rate of degradation and resynthesis by rumen micro-organisms (Tagari et al. 1964 ; Henderickx \& Martin, I963). It seemed important therefore to compare the utilization of the nitrogen given in a diet containing oil cake as represented by soya-bean meal (SBM) with that of the $\mathrm{N}$ of lucerne hay, when the remainder of the diet in both instances contained neither readily available carbohydrates nor digestible protein. The amino acid 
contents of the proteins contained in SBM and in lucerne hay do not differ significantly (Block \& Weiss, 1956). However, the contents of non-protein N (NPN) and particularly the contents of free amino acids differ considerably in these two products (see Tagari, Krol \& Bondi, 1965). It is well known that amino acids are used by rumen bacteria (Annison, 1956) and that they may have a stimulating effect upon the bacteria (Gilroy, 1958). It has also been shown (Bryant, Small, Bouma \& Chu, 1958) that some rumen bacteria need peptides for growth, and peptides are usually readily available in the NPN fraction of the diet.

The carbohydrate fractions of SBM and lucerne hay differ markedly. SBM is very low in crude fibre compared with lucerne hay, and the digestibility of the $\mathrm{N}$-free extractives fraction is much higher in SBM than in lucerne hay. This fraction in SBM could be regarded as consisting mainly of readily digestible carbohydrates, whereas in lucerne hay a considerable part of it consists of lignin and pentosans of low digestibility (Guggolz, Herring \& Kohler, I967).

Some preliminary results showing that there are differences in the efficiency with which the proteins of SBM and lucerne hay are utilized by ruminants have already been reported by Tagari et al. (1965). The work described in this paper deals mainly with $\mathrm{N}$ metabolism in vivo. Further, the influence of the protein source on the biosynthetic power of the microbial population has been studied by the artificial rumen technique. Attention has been paid also to metabolic changes occurring in the rumen which depend primarily on the carbohydrates of the diet, but which are also influenced by interactions between proteins and carbohydrates and by resulting changes in dehydrogenase activity and in the concentrations of volatile fatty acids.

\section{EXPERIMENTAL}

\section{Animals, treatments and design}

Male and female sheep of the Awassi breed were used. They were $\mathrm{I}-\mathrm{I} \cdot 5$ years old, weighed $45^{-8} 3 \mathrm{~kg}$ and were still growing. The composition and the feeding values of the feeds are given in Table $\mathrm{r}$. The Scandinavian Feed Unit values were calcuated from the analyses of samples of the feeds used in the experiments and from digestibility coefficients obtained previously in this laboratory (Bondi \& Neumark, 1960).

Table I. Composition (\%) and feeding value of the feedstuffs

\begin{tabular}{|c|c|c|c|c|c|c|c|c|}
\hline Feed & Water & $\begin{array}{l}\text { Crude } \\
\text { protein }\end{array}$ & Fat & Ash & $\begin{array}{c}\text { Crude } \\
\text { fibre }\end{array}$ & $\begin{array}{l}N \text {-free } \\
\text { extract }\end{array}$ & $\begin{array}{c}\text { Digestible } \\
\text { crude } \\
\text { protein }\end{array}$ & $\begin{array}{l}\text { Feed } \\
\text { units in } \\
\text { roo kg }\end{array}$ \\
\hline Lucerne hay & 14.0 & $20 \cdot 0$ & $2 \cdot 3$ & $6 \cdot 8$ & $21 \cdot 6$ & $35 \cdot 3$ & 14.0 & $50 \cdot 0$ \\
\hline $\begin{array}{l}\text { Toasted } \\
\text { soya-bean } \\
\text { meal }\end{array}$ & II 5 & $48 \cdot 0$ & I.5 & $6 \cdot 8$ & $4 \cdot 2$ & $28 \cdot 0$ & $44 \cdot 2$ & $128 \cdot 2$ \\
\hline $\begin{array}{l}\text { Cottonseed } \\
\text { hulls }\end{array}$ & $I I \cdot 6$ & $3 \cdot 3$ & 0.9 & $3 \cdot 1$ & $40 \cdot 7$ & $40^{\circ} 4$ & $\circ$ & 30.9 \\
\hline
\end{tabular}

The amounts of food to be offered to the sheep were calculated from the feeding standards used by Tagari et al. (1964). The animals were supplied once daily with Io $\mathrm{g}$ dicalcium phosphate, and 50000 i.u. vitamin A were given weekly to the sheep 
when they were receiving rations containing SBM. The sheep always had free access to water and a mineral lick.

The animals were fed twice daily. The morning ration, given at $07.30 \mathrm{~h}$, contained the main protein feeds, whereas the cottonseed hulls were available to the animals throughout the day. Four experiments were done, all of them based on a cross-over design, in which the animals allotted to the SBM diet in the first experimental period were switched to the lucerne diet in the second period, and vice versa. Each of the two contiguous treatments lasted approximately 38 days as follows: after I week of a gradual transfer of the sheep to the experimental diets and a preliminary period of

Table 2. Details of the experimental design, animal allocation, treatments and metabolites studied in the various experiments

(All the experiments had a cross-over design)

Criteria examined

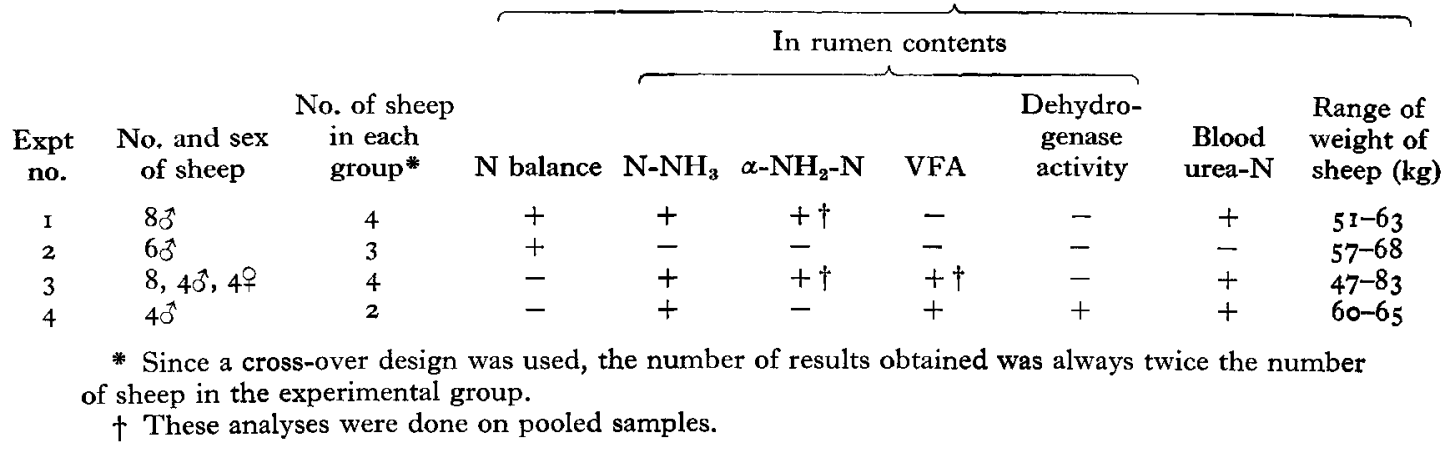

14 days (cf. Tagari et al. 1964), the $\mathrm{N}$ balance determinations were made for 10 days. After that the sheep were kept for an additional week on the same diets, and samples of rumen liquor and blood urea were taken on each of 3 alternate days.

The number of sheep used in each of the experiments, their weight, their allocation to the different experiments and the metabolites studied are given in Table 2. In Expt 3 four animals were allocated to each group, two heavy animals (one male and one female) and two light animals (one male and one female). The aim of using such heterogeneous groups was to find whether other factors in addition to the nature of the ration would affect the variation in the concentration of metabolites.

The two rations investigated contained either lucerne hay or toasted extracted SBM as the main source of digestible protein. Toasted SBM was chosen in preference to the untoasted since the protein contained in toasted meals has been found to be better utilized by the ruminant (Sherrod \& Tillman, ı962; Tagari, Ascarelli \& Bondi, 1962; Chalmers, Jayasinghe \& Marshall, 1964). Cottonseed hulls were given to satisfy the energy requirement of the sheep. The amounts of feeding-stuffs ingested during the balance experiments are given in Table 3 . These amounts were calculated according to the average weights of the animals during the trials. The amounts of cottonseed hulls used during the second trial were slightly restricted in order to avoid live-weight gain; it is known that adult Awassi rams will readily gain weight. It is clear from Table 3 
that in both experiments the amounts of energy consumed by the sheep kept on the lucerne hay were practically the same as those consumed when the SBM diets were given. The rations used in Expt I were the same as those used in Expts 3 and 4.

Table 3. Composition and feeding value of rations consumed during $N$ balance experiments

\begin{tabular}{|c|c|c|c|c|c|c|}
\hline \multirow[b]{2}{*}{ Expt no. } & \multirow[b]{2}{*}{ Source of digestible protein } & \multicolumn{4}{|c|}{ Daily intake } & \multirow[b]{2}{*}{$\begin{array}{l}\text { Weight* of } \\
\text { ram (mean }\end{array}$} \\
\hline & & SBM & Lucerne hay & $\begin{array}{l}\text { Cottonseed } \\
\text { hulls }\end{array}$ & $\begin{array}{c}\text { Total feed } \\
\text { units }\end{array}$ & \\
\hline \multirow[t]{2}{*}{ I } & $\begin{array}{l}\text { SBM: } \\
\quad \text { feed units }\end{array}$ & $\begin{array}{l}0.166 \\
0.213\end{array}$ & - & $\begin{array}{l}1 \cdot 506 \\
0.465\end{array}$ & $\overline{0.678}\}$ & $58 \cdot 9$ \\
\hline & $\begin{aligned} \text { Lucerne hay: } \mathrm{kg} \\
\text { feed units }\end{aligned}$ & - & $\begin{array}{l}0.504 \\
0.252\end{array}$ & $\begin{array}{l}1 \cdot 257 \\
0.383\end{array}$ & $\overline{0.640}\}$ & $56 \cdot 8$ \\
\hline \multirow[t]{3}{*}{2} & $\begin{array}{l}\mathrm{SBM}: \mathrm{kg} \\
\quad \text { feed units }\end{array}$ & $\begin{array}{l}0.175 \\
0.224\end{array}$ & - & $\begin{array}{l}1 \cdot 154 \\
0 \cdot 355\end{array}$ & $\left.\begin{array}{c}- \\
0.579\end{array}\right\}$ & $62 \cdot 6$ \\
\hline & $\begin{array}{l}\text { Lucerne hay: } \mathrm{kg} \\
\text { feed units }\end{array}$ & - & $\begin{array}{l}0.519 \\
0.260\end{array}$ & $\begin{array}{l}1.023 \\
0.316\end{array}$ & $\left.\begin{array}{c}- \\
0.576\end{array}\right\}$ & $63 \cdot 1$ \\
\hline & & SBN & ya-bean meal. & & & \\
\hline
\end{tabular}

* Mean weight during the experimental period.

\section{Sampling}

Samples of rumen liquor were removed by suction through a polythene stomach tube of internal diameter $5 \mathrm{~mm}$. Blood samples of $5 \mathrm{ml}$ were withdrawn from the jugular vein, using heparin as anticoagulant, and their urea content was determined immediately by the method of Conway (1957). Other details about the sampling and times of sampling have already been published (Tagari et al. 1964). Samples of rumen liquor and blood were obtained on each of 3 alternate days unless otherwise stated.

\section{Artificial rumen technique}

For studies of protein synthesis by rumen micro-organisms a two-stage incubation was carried out as follows: Io $g$ of the powdered feed $(60 \mathrm{mesh})$ were incubated at $3^{\circ}$ for $4 \mathrm{~h}$ with a mixture of $60 \mathrm{ml}$ rumen liquor (withdrawn from sheep receiving the ration under investigation) and $40 \mathrm{ml}$ artificial saliva $(\mathrm{pH} 6 \cdot 8)$, after which the mixture was centrifuged at $2^{\circ}$ for $20 \mathrm{~min}$ at $20000 \mathrm{~g}$. The clear supernatant liquid was then used as a nutrient medium by placing in it a dialysis tube containing $15 \mathrm{ml}$ rumen liquor, which was obtained $2 \mathrm{~h}$ after the morning feed had been eaten, and $200 \mathrm{mg}$ powdered cottonseed hulls as a source of energy. In control experiments artificial saliva was substituted for the nutrient medium. The incubation was ended and the protein precipitated after $8 \mathrm{~h}$ by acidifying with trichloroacetic acid to a final concentration of $10 \%(\mathrm{w} / \mathrm{v})$. The mixture was then centrifuged at $5000 \mathrm{~g}$ and the supernatant liquid discarded. The amount of $\mathrm{N}$ precipitated was determined by the Kjeldahl method (see Tagari et al. 1964).

\section{Collection of urine and faeces for determination of $N$ balance}

Urine was collected through a rubber funnel attached to the abdomen of the rams. The urine passed by gravitation through a rubber tube to a plastic bottle and was 
collected in $\mathrm{H}_{2} \mathrm{SO}_{4}$. The funnel was rinsed three times daily with $4 \%$ boric acid solution. The faeces collected were kept in a deep-freeze. The faeces were sampled after suitable blending, and $\mathrm{N}$ was then determined in the wet faeces, since drying caused a loss of $5-10 \%$ of the total $\mathrm{N}$ of the faeces.

\section{Chemical methods}

The solubility of the proteins, the NPN content of the feeds and the free amino acid content of dialysed rumen liquor were determined as already described by Tagari et al. (1962). Total $\mathrm{N}$ was determined by the Kjeldahl method.

\section{Total metabolic activity}

The total metabolic activity of the bacteria in the rumen was determined by the dehydrogenase activity of the rumen liquor towards triphenyltetrazolium chloride (TTC). The method used previously for estimating dehydrogenase activity of soil bacteria was applied here to rumen organisms (Tagari et al. 1964) and the simpler modification adopted by Y. Dror, H. Tagari and A. Bondi (1969, unpublished) was used. This modification involved the use of reduced volumes $(0.5 \mathrm{ml}$ rumen liquor, $0.15 \mathrm{ml}$ of $5.4 \%$ TTC); the mixture was covered with $0.2 \mathrm{ml}$ liquid paraffin, and the reaction was stopped by the addition of $5.5 \mathrm{ml}$ isopropanol.

\section{$V F A$ determinations in rumen liquor}

The procedures of Erwin, Marco \& Emery (I96I) and Packett \& McCune (1965) were used. The column contained carbowax $20 \mathrm{M}$ as the liquid phase. The injection port was filled with fine glass wool which had been treated with orthophosphoric acid, rinsed with methanol and dried at $105^{\circ}$. This procedure has been found to be helpful in eliminating the appearance of shadowing (M. A. Katz, personal communication). The determinations were made in a Packard Gas-Chromatograph fitted with a flame ionization detector.

\section{Calculation and statistical analysis}

To express the variation of concentrations of metabolites with time as a single characteristic number the following calculation was used: the curves giving the concentrations against time were integrated by measuring the areas below them, and the result was divided by the duration of the daily sampling period, i.e. $8 \mathrm{~h}$ for rumen liquor and $\mathrm{i} 4 \mathrm{~h}$ for blood urea. This characteristic value will be referred to as 'weighted average'.

Statistical analyses and calculation of true digestibility were as already described (Tagari et al. 1964).

\section{RESULTS}

\section{Solubility of $N$ fraction of the feeds and its free amino acids composition}

The results for soluble protein, NPN and free amino acids are given in Tables 4 and 5 .

Lucerne hay and SBM differ considerably in their contents of soluble NPN and of free amino acids which form part of the NPN. The high concentrations of proline, 
alanine, serine, threonine and valine present in free form in lucerne hay are striking, particularly in view of the fact that the contents of these amino acids in lucerne protein do not show a similar pattern (Block \& Weiss, 1956).

Table 4. Contents of soluble protein nitrogen and non-protein nitrogen $(N P N)$ in lucerne hay and soya-bean meal (SBM) expressed as a percentage of the total $N$

$\begin{array}{lccc} & \text { Soluble protein } & & \\ & \text { N } & \text { NPN } & \text { Total soluble N } \\ \text { Lucerne hay } & 4.5 & 25.5 & 30.0 \\ \text { Toasted SBM } & 13.5 & 1.5 & 15.0\end{array}$

Table 5. Contents* ( $\mu$-equiv./100 g) of free amino acids in lucerne hay and toasted soya-bean meal

Amino acid

Alanine

Aspartic acid

Glutamic acid

Glycine

Leucine

Lysine + ornithine

Methionine

Phenylalanine

Proline

Serine

Threonine

Valine
Lucerne hay

2355

430

490

393

I 32

I 49

422

452

8053

3280

I 577

1232

I 8965
Soya-bean meal

82

IOI

136

12

I

I I

-

8

$5^{8}$

12

$-$

420

* Determined on a freeze-dried dialysate of the $\mathrm{N}$ fraction of the feed dissolved in artificial saliva.

\section{Measurement of $N$ balance}

The mean values for $\mathrm{N}$ intake, $\mathrm{N}$ balance values and digestibility coefficients obtained in Expts $\mathrm{I}$ and 2 are presented in Table 6.

The average results of both experiments (see Table 6) proved the superiority of the protein of lucerne hay over that of SBM with respect to its $\mathrm{N}$ retention. The greater value for lucerne hay protein was shown also by the fact that a much lower percentage of digested $\mathrm{N}$ was excreted in the urine when lucerne hay rather than SBM served as the sole protein source. This suggests that there are differences in the ways in which the nitrogenous compounds from these two sources are metabolized. The apparent digestibility of $\mathrm{N}$ in both rations was very low because of the presence of considerable amounts of cottonseed hulls, but even when the values for apparent digestibility were adjusted by assuming that the protein of the cottonseed hulls was not digested at all, the adjusted digestibility values were still not very high.

The true digestibility coefficients for the $\mathrm{N}$ constituents of the lucerne hay, calculated according to Mitchell (I943), did not differ significantly from those for the $\mathrm{N}$ constituents of SBM.

The influence of the two different protein sources examined on the $\mathrm{N}$ retention was 
Vol. 23

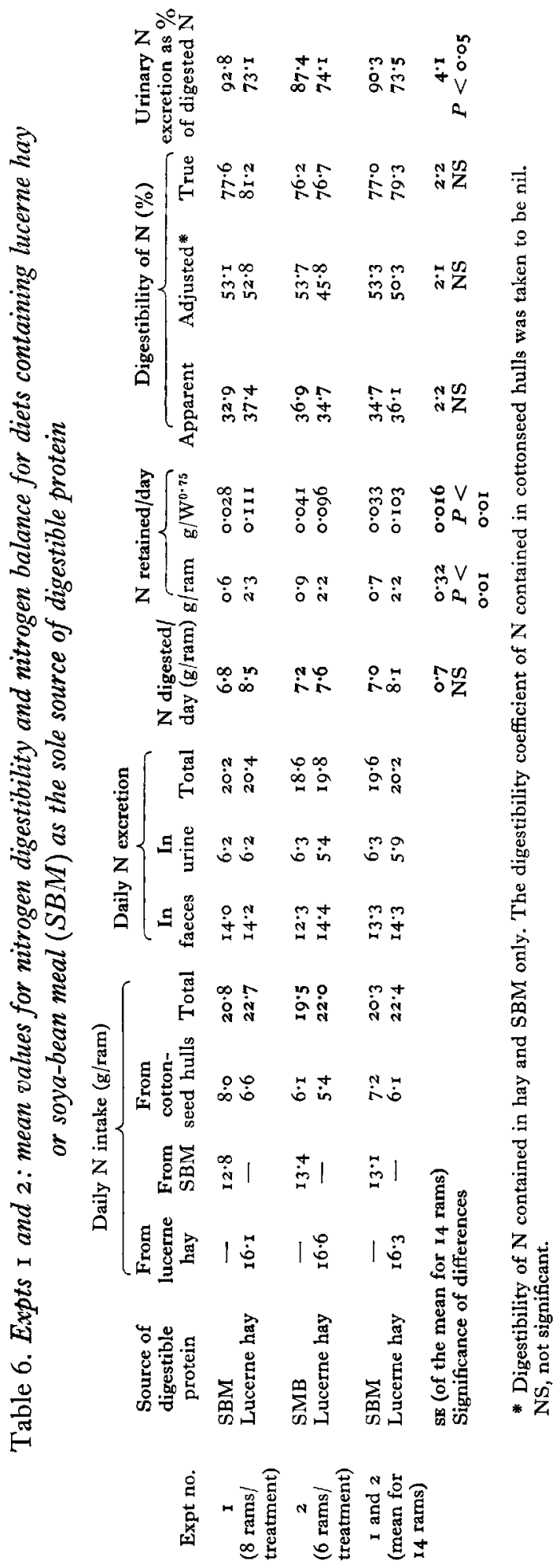


highly significant. This difference in the $\mathrm{N}$ retention depended only on the nature of the protein feedstuffs used, since both groups of animals obtained equal amounts of energy (see Table 3 ) and the differences in the amounts of digestible protein ingested in both groups were small, particularly in the second experiment. The differences in the intake of digestible protein in the first experiment resulted from the fact that, when the rations were computed, digestibility coefficients previously determined in this laboratory were used (Bondi $\&$ Neumark, r 960 ). The calculation of the actual intakes of digested protein given in Table 6 , however, has been based on the digestibility coefficients found in this work; the latter coefficients were depressed because of the presence of cottonseed hulls in the diets. In Expt 2 this fact was taken into account, and almost equal amounts of digestible protein were ingested by both groups of animals, and the more efficient retention of the $\mathrm{N}$ of the lucerne hay ration was confirmed. This change induced obviously a significant feed $\times$ experiment interaction concerning amounts of $\mathrm{N}$ digested, but the results for $\mathrm{N}$ retention, $\mathrm{N}$ digestibility and urinary $\mathrm{N}$ excretion as a percentage of digested $\mathrm{N}$ were very similar in both experiments and the interactions were not significant. The food intakes of the sheep in both experimental groups contained the same amount of energy (Table 3). Feed unit values previously determined (Table I) were used to calculate the energy contents of the diets since, according to Forbes \& Garrigus (1949), the energy value of feedstuffs, unlike their digestible protein content, is not affected by the presence of cottonseed hulls in the diet.

\section{Observations on rumen contents}

In order to explain the differences in $\mathrm{N}$ retention between the two feeds (lucerne hay and SBM) experiments were done to determine what changes occurred in the concentrations of ammonia and of certain amino acids in the rumen liquor and of urea in the blood. Samples of rumen liquor and blood were taken from sheep given these feeds in Expts I, 3 and 4.

Ammonia and urea concentrations. Mean results for the $\mathrm{NH}_{3}-\mathrm{N}$ content of the rumen liquor and of the urea content of the blood for Expts I and 3 are given in Fig. I. Weighted average values of the time-concentration curves for $\mathrm{NH}_{3}-\mathrm{N}$ in rumen liquor and for urea-N in blood are given in Table 7. Consistently, higher concentrations of $\mathrm{NH}_{3}$ were obtained with lucerne hay than with SBM. Inversely the peaks of the time-concentration curves as well as the weighted average values for blood urea were found to be much higher for sheep given SBM than for those given lucerne hay (see Fig. $\mathrm{I}$ and Table 7). If it is assumed that most of the blood urea is not utilized by the animal, apart from a small part of it which is re-cycled through the saliva into the rumen (see McDonald, 1948; Houpt, 1959), it may be concluded that most of the blood urea can be regarded as a final and non-utilizable form of the digested $\mathrm{N}$, and the level of blood urea may be taken as being inversely related to the efficiency of utilization of protein of the diet (Tagari et al. 1964; Abou Akkada \& el-Sayed Osman 1967).

The observed differences between the concentrations of $\mathrm{NH}_{3}-\mathrm{N}$ in rumen liquor of sheep given the two different diets were $0.84, \mathrm{r} \cdot 6$ and $\mathrm{r} \cdot 7$ m-equiv. $\mathrm{NH}_{3}-\mathrm{N} / \mathrm{l}$. 
rumen liquor in Expts I, 3 and 4, respectively, revealing a significant feed $\times$ experiment interaction, whereas the diet differences for blood urea $\mathrm{N}$ concentrations were $2 \cdot 38$ and 2.42 for Expts I and 3, respectively, where obviously the feed $\times$ experiment interaction was not significant.

High rumen ammonia levels, like high blood urea values, are generally considered as indicating relatively poor $\mathrm{N}$ utilization. However, rumen ammonia, unlike blood urea, can be used for the synthesis of bacterial protein which is then utilized by the host animal. This may explain why higher $\mathrm{N}$ retentions and higher rumen $\mathrm{NH}_{3}$ levels could both occur after ingestion of lucerne hay.

Table 7. Mean values for rumen $\mathrm{NH}_{3}-\mathrm{N}$ and blood urea- $\mathrm{N}$ concentrations in sheep given rations containing soya-bean meal $(S B M)$ or lucerne hay as the sole source of digestible $N$, obtained in Expts I, 3 and $4^{*}$

(Values are expressed as weighted averages of $\mathrm{m}$-equiv. $\mathrm{N} / \mathrm{rumen}$ liquor or blood)

$\begin{array}{lccccc}\text { Metabolite } & \begin{array}{c}\text { No. of } \\ \text { animalst }\end{array} & \text { Lucerne hay } & \text { SBM } & \text { SE } & \begin{array}{c}\text { Significance of } \\ \text { differences }\end{array} \\ \text { Rumen } \mathrm{NH}_{3}-\mathrm{N} & 20 & 7.6 & 6.2 & 0.35 & P<0.05 \\ \text { Blood urea-N } & 16 & 4 . \mathrm{I} & 6.5 & 0.6 \mathrm{I} & P<0.05\end{array}$

* For experimental details see Table 2 .

+ Results for each sheep were obtained on 3 alternate days, five times per day.
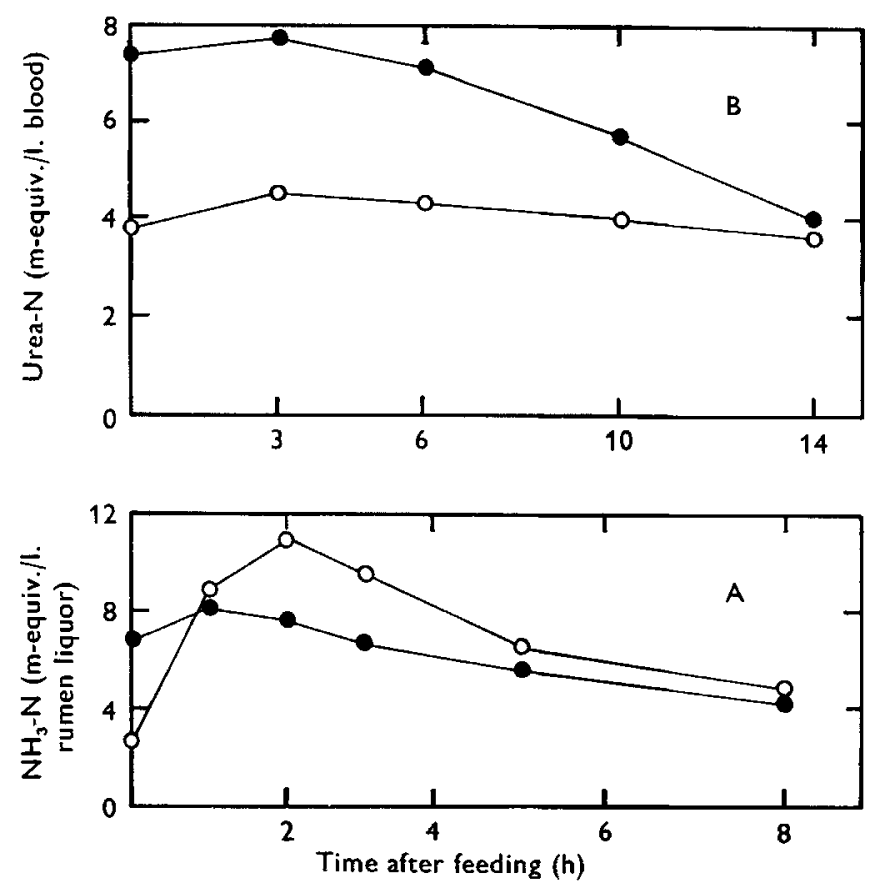

Fig. r. Expts 1 and 3. Ruminal ammonia (A) and blood urea-N (B) concentrations for sheep given soya-bean meal $(C)$ or lucerne hay $(O)$ as the sole source of digestible nitrogen. Each point represents an average of results obtained with sixteen sheep on 3 alternate days each. 
Concentrations of rumen ammonia and blood urea in the early morning when SBM was given exceeded the corresponding concentrations measured in the evening (see Fig. I). Apparently when the growth rate of the rumen bacteria declined overnight, probably as a result of shortage of available carbohydrates, the rate of formation of $\mathrm{NH}_{3}$ exceeded the rate of its uptake by micro-organisms for protein synthesis, with the result that the $\mathrm{NH}_{3}$ concentration in the rumen and urea concentration in the blood increased during the night (see Moir \& Somers, 1957; Tagari et al. 1962).

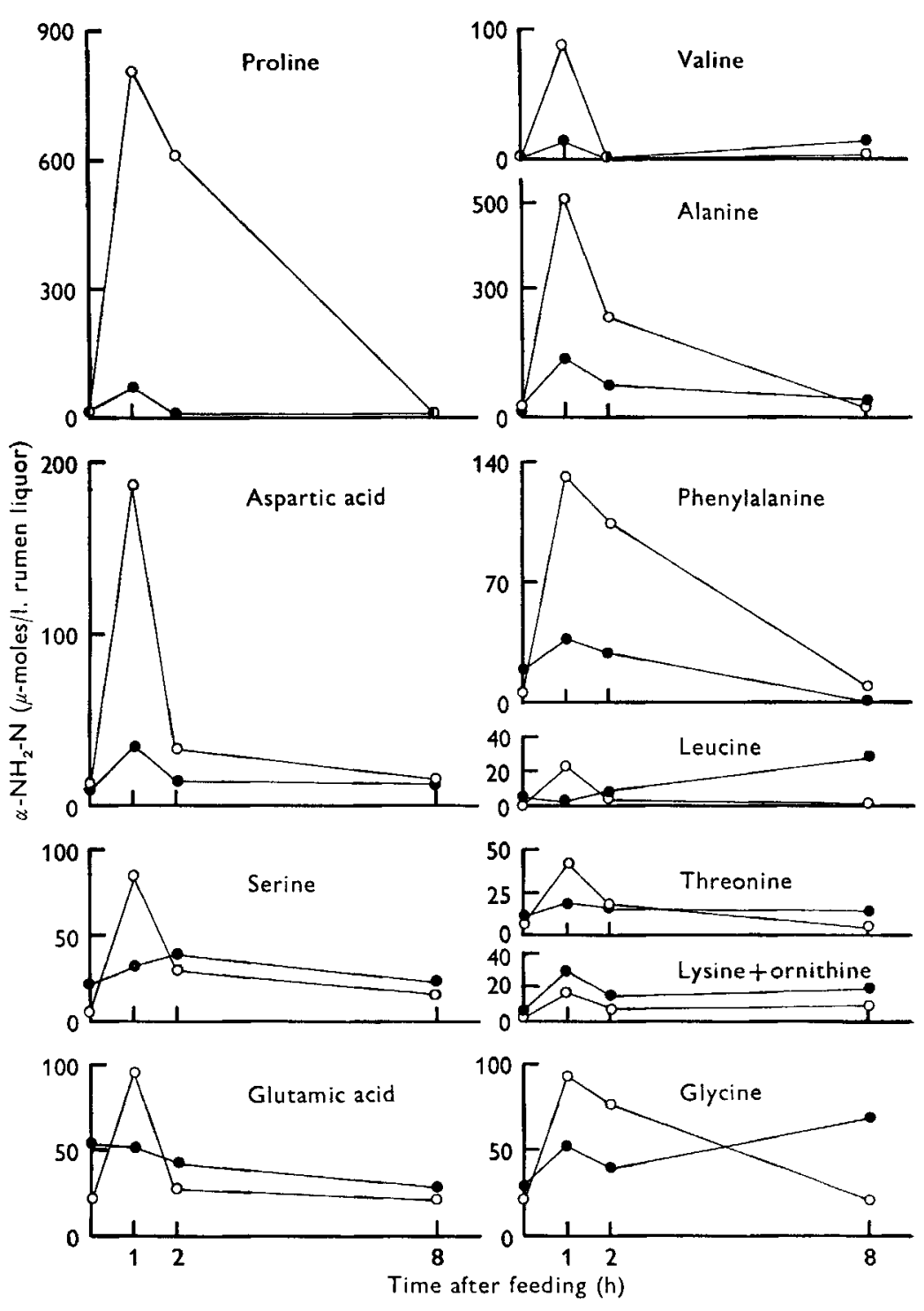

Fig. 2. Expts $I$ and 3. Concentrations of free amino acids in the rumen liquor of sheep given soya-bean meal $(\Theta)$ or lucerne $(O)$ as the sole source of digestible nitrogen. Each point represents an average of two determinations carried out on mixed samples obtained from sixteen animals on 3 alternate days. 
Amino acid concentrations. Average values and fluctuations in the concentrations of certain free amino acids occurring in rumen liquor while the sheep were receiving each of the two feeds are shown in Fig. 2. For most of the free amino acids in the rumen liquor of sheep receiving lucerne hay the pattern was similar to that of the free amino acids in the feed (see Table 5). As expected, the absolute values were much higher in the rumen liquor of sheep given the lucerne diet than in the rumen liquor of sheep receiving the SBM diet. No great differences were found before and $8 \mathrm{~h}$ after feeding with either kind of feed. Considerable differences, however, were found $\mathrm{I}$ and $\mathbf{2} \mathrm{h}$ after ingestion of the feeds. The very high concentrations of alanine and proline found after feeding lucerne hay and the rapid decline in these concentrations that had occurred

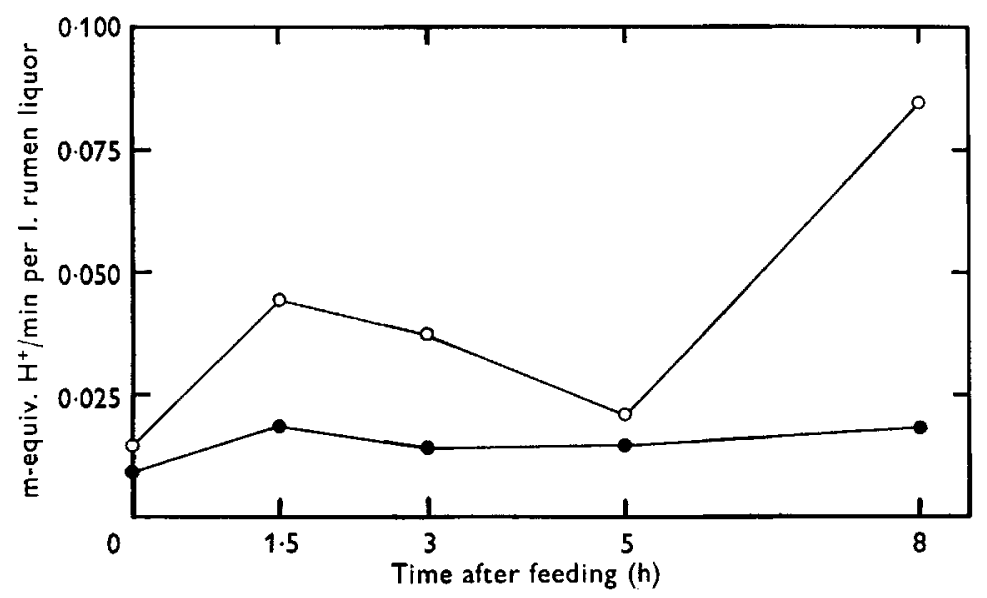

Fig. 3. Expt 4. General bacterial activity as measured by dehydrogenase activity in rumen liquor of sheep given soya-bean meal $(\bullet)$ or lucerne hay $(O)$ as the sole source of digestible nitrogen. Each point represents an average of results obtained with four sheep on 3 alternate days.

by $8 \mathrm{~h}$ were striking. Clarke, Ellinger $\&$ Phillipson (1966) also found that proline disappeared from the rumen very rapidly. It is worth noting that, whenever valine appeared in considerable amounts $\mathrm{I} h$ after giving lucerne hay, it disappeared very quickly, only traces being detectable $\mathrm{r} h$ later. The concentrations of most of the amino acids decreased considerably during the 2nd hour after the lucerne hay was given, but the concentrations of ammonia in the rumen liquor were still increasing during that hour (Figs. I and 2). This clearly suggests that the $\mathrm{NH}_{3}$ is formed by deamination of amino acids.

Dehydrogenase activity. The dehydrogenase activity towards TTC was determined in rumen liquor obtained from sheep, kept on both kinds of ration, in Expt 4. Since the levels of $\mathrm{NH}_{3}$ concentrations found in this experiment were very similar to those determined in Expts I and 3, the general validity of the results of the dehydrogenase activity may be assumed. The results for dehydrogenase activity are shown graphically in Fig. 3 and the weighted average values were $0.04 \pm 0.002$ and $0.016 \pm 0.002 \mathrm{~m}$ equiv. $\mathrm{H}^{+} / 1$. rumen liquor per $\mathrm{min}$ in rumen liquor of sheep given lucerne hay and SBM respectively. 
VFA production. The results for VFA concentrations are given in Fig. 4. Without exception the concentrations were higher throughout for the sheep that were receiving lucerne hay. The differences were not of the same magnitude for each of the acids examined but they were all generally greatest in the first hour or two after feeding and then declined. The weighted average values of the time-concentration curves and

Table 8. Expts 3 and 4. Mean* concentration of volatile fatty acids in rumen liquor of sheep given lucerne hay or soya-bean meal $(S B M)$ as the sole source of digestible nitrogen

(Weighted average values are expressed as $\mathrm{m}$-moles/1. rumen liquor)

\begin{tabular}{|c|c|c|c|c|c|c|c|c|}
\hline Diet & $\begin{array}{c}\text { Acetic } \\
\left(\mathrm{C}_{2}\right)\end{array}$ & $\begin{array}{l}\text { Propionic } \\
\quad\left(\mathrm{C}_{3}\right)\end{array}$ & $\begin{array}{c}\text { Butyric } \\
\left(\mathrm{C}_{4}\right)\end{array}$ & $\begin{array}{c}\text { Isovaleric } \\
\left(\mathrm{C}_{5}\right)\end{array}$ & $\begin{array}{c}\text { Valeric } \\
\left(\mathrm{C}_{5}\right)\end{array}$ & $\begin{array}{c}\text { Caproic } \\
\left(\mathrm{C}_{6}\right)\end{array}$ & Total & $\begin{array}{l}\text { Ratio, } \\
\mathrm{C}_{2}: \mathrm{C}_{3}\end{array}$ \\
\hline \multicolumn{9}{|c|}{ Concentration (m-moles/1.) } \\
\hline cerne & $49 \cdot 00$ & $11 \cdot 70$ & 4.40 & 0.50 & 0.70 & 0.40 & $66-70$ & 4.20 \\
\hline & $42 \cdot 40$ & 8.05 & 3.40 & 0.35 & 0.40 & 0.25 & $54 \cdot 85$ & $5 \cdot 26$ \\
\hline \multicolumn{9}{|c|}{ Proportion (m-moles/ s 00 m-moles) } \\
\hline cerne & $\begin{array}{l}73 \cdot 50 \\
77 \cdot 30\end{array}$ & $\begin{array}{l}17.50 \\
14.67\end{array}$ & $\begin{array}{l}6.60 \\
6.20\end{array}$ & $\begin{array}{l}0.75 \\
0.64\end{array}$ & $\begin{array}{l}I .05 \\
0.73\end{array}$ & $\begin{array}{l}0.60 \\
0.46\end{array}$ & $\begin{array}{l}100.00 \\
100.00\end{array}$ & \\
\hline
\end{tabular}

* Combined average of results obtained in Expts 3 and 4 . In Expt 3 analyses were carried out on mixed samples of rumen liquor obtained from eight sheep. In Expt 4 separate determinations were made on rumen liquor obtained from four sheep. The coefficient of variation of the results of Expt 4 was about $5 \%$. The two experiments gave similar results.

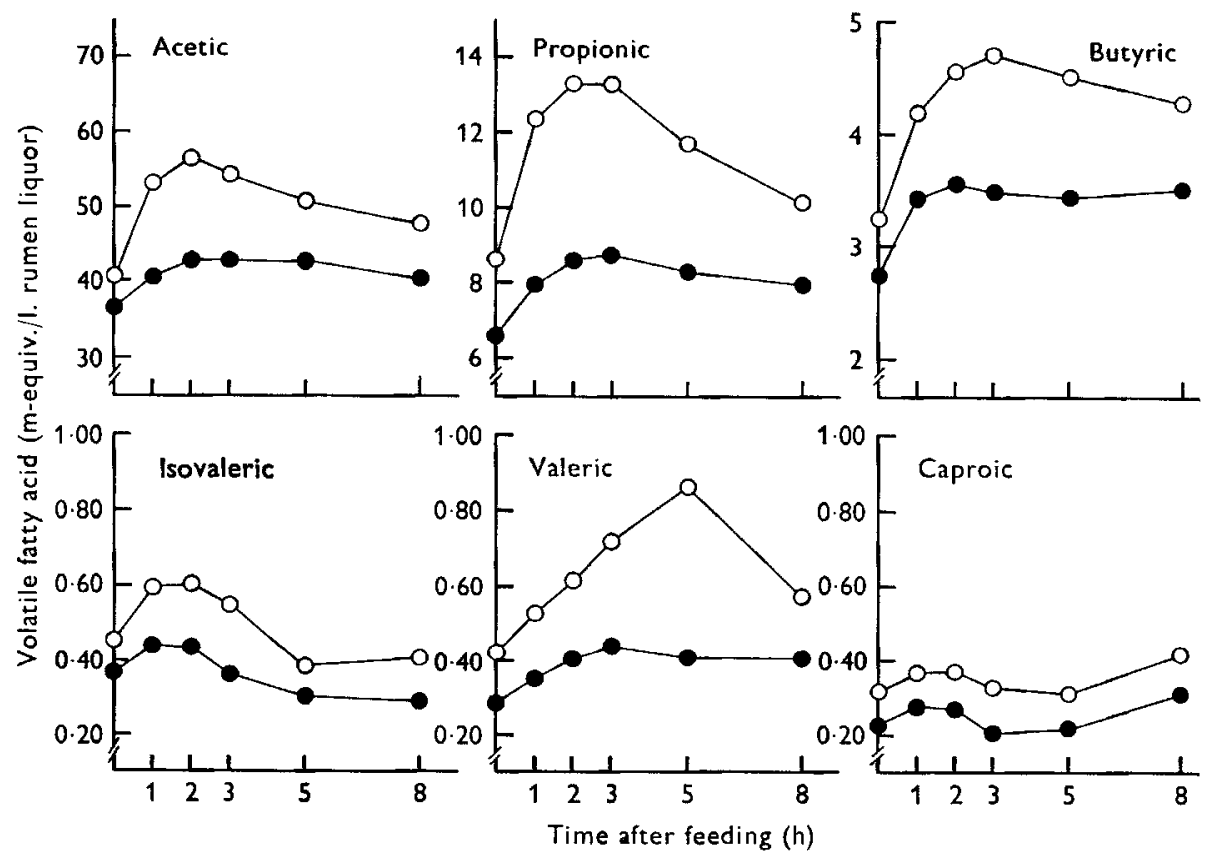

Fig. 4. Expts 3 and 4. Volatile fatty acids concentration in rumen liquor of sheep given soyabean meal (O) or lucerne hay $(O)$ as the sole source of digestible nitrogen. Each point represents an average result of determinations carried out on rumen liquor samples withdrawn from eight and four sheep in Expts 3 and 4, respectively. For full details see Table 2. 
their proportions are given in Table 8 , where it can be seen that the concentration of total volatile fatty acids in the rumen liquor of the sheep receiving lucerne hay was some $21 \%$ higher than for the sheep receiving SBM.

It may be noted that particularly the concentrations of the acids higher than $\mathrm{C}_{2}$ found after ingesting the lucerne hay were greater than those present in the rumen

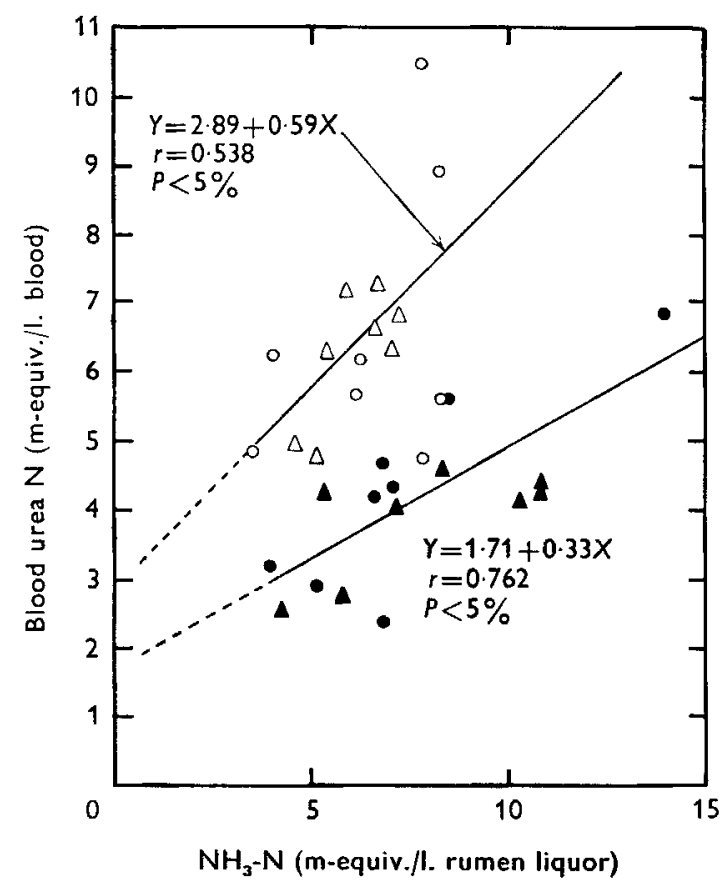

Fig. 5. Expts I and 3. Dependence of blood urea concentration upon ruminal ammonia concentration in sheep given soya-bean meal $(0, \Delta)$ or lucerne hay $(\boldsymbol{\Delta}, \Delta)$ as the sole source of digestible nitrogen. Each point represents the weighted average of results obtained on 3 alternate days, five samplings per day (i.e. fifteen determinations for each sheep). $(0,0)$, Expt I ; $(\triangle, \Delta)$, Expt 3 .

Table 9. Biosynthesis of protein in the artificial rumen by the action of rumen liquor withdrawn from sheep given soya-bean meal (SBM) or lucerne hay as sole source of digestible protein*

$\begin{array}{ccccc} & \begin{array}{c}\text { Soya-bean } \\ \text { meal }\end{array} & \text { Lucerne hay } & \text { SE } & \begin{array}{c}\text { Significance of } \\ \text { differences }\end{array} \\ \begin{array}{c}\text { Protein found after incubation } \\ \text { with rumen liquor (mg) }\end{array} & 54.3 & 37.7 & - & - \\ \begin{array}{c}\text { Protein found after incubation } \\ \text { with artificial saliva (blank value) } \\ \text { (mg) }\end{array} & 47.0 & 26.2 & - & - \\ \begin{array}{c}\text { Protein synthesized (the excess } \\ \text { found above the blank values) (mg) }\end{array} & 7.3 & 11.5 & 0.83 & P<0.01 \\ \begin{array}{c}\text { Protein synthesized, as a percentage } \\ \text { of blank values (mg) }\end{array} & \text { I5.5 } & 43.9 & 6.00 & P<0.01\end{array}$

* Mean values for eight and four incubations in Expts $\mathbf{I}$ and 3, respectively. 
liquor of the animals kept on the SBM diet. The weighted average values of $\mathrm{C}_{3}$ in rumen liquor of the lucerne hay group surpassed those in rumen liquor of the SBM group by about $45 \%$, of $\mathrm{C}_{4}$ by $29 \%$ and of $\mathrm{C}_{5}$ by $75 \%$ (average of both experiments).

Synthesis of protein in the artificial rumen. In these series of experiments the ability of rumen liquor to synthesize protein from NPN compounds extracted from lucerne hay and SBM was studied. Extracts of both feeds were subjected to the action of rumen liquor withdrawn from sheep given lucerne hay and from those given SBM. One series of experiments was carried out with rumen liquor withdrawn from the sheep used in Expt I and the second series of experiments with rumen liquor from the sheep of Expt 3. Mixed samples of rumen liquor withdrawn from four sheep on each treatment were used. The average results are given in Table 9, where it can be seen that the ability of the rumen liquor to synthesize protein was considerably greater when the sheep received lucerne hay than when they received SBM. The difference was somewhat similar to the differences recorded for dehydrogenase activity (see p. 465). It will be remarked (Table 9) that the blank values found after incubation of extracts of SBM with rumen artificial saliva surpassed considerably those obtained after incubation of extracts of lucerne hay with artificial saliva. This appeared to be caused by the presence of greater amounts of soluble proteins and suspended small particles in the extracts from SBM than in the extracts from lucerne hay.

\section{DISCUSSION}

The results of balance experiments presented here showed that the sheep utilized the protein of lucerne hay more efficiently than that of SBM when both feeds served as the sole source of protein in the diets. In revealing the superiority of lucerne protein over that of SBM this finding fully agreed with the results obtained for changes in the concentrations of blood urea, amino acids and medium-chain fatty acids in the rumen liquor. The greater activity of the rumen micro-organisms when lucerne hay was given was also indicated by the enhanced dehydrogenase activity found in the rumen liquor of sheep receiving lucerne hay, and the greater ability of such rumen liquor to synthesize protein. As already explained above (p. 462), blood urea concentrations are likely to be lower when dietary protein is efficiently utilized than when it is used less efficiently, and in fact the concentrations of urea in blood were lower in the sheep given the lucerne hay diet than in the sheep given SBM.

As has already been pointed out, since part of the $\mathrm{NH}_{3}$ of the rumen liquor can be used for protein synthesis, high rumen $\mathrm{NH}_{3}$ values, unlike high blood urea values, are not incompatible with relatively more efficient utilization of the $\mathrm{N}$ of the diet. The dependence of blood urea on rumen $\mathrm{NH}_{3}$ concentrations has been previously considered (Lewis, 1957; Tagari et al. 1962, 1964). This dependence was found to be significant only when the results for each diet were separately examined (see Fig. 5). Furthermore the regression coefficient for the increase of blood urea $\mathrm{N}$ with the increase in rumen $\mathrm{NH}_{3}-\mathrm{N}$ was 0.59 with SBM $(0.54$ and 0.72 for Expts $\mathrm{I}$ and 3$)$ and 0.33 with the lucerne diet $(0.24$ and 0.42 for Expts I and 3$)$. This is a considerable 
difference and, although it was not significant, it was observed in two different experiments. These observations indicate that there was a better utilization of the $\mathrm{NH}_{3}$ formed in the rumen when the sheep were given lucerne hay (cf. also Table 9).

The comparatively high concentrations of various amino acids, particularly proline, alanine and valine, and their rapid disappearance from the rumen liquor of the animals receiving lucerne were associated with high concentrations of medium-chain fatty acids, such as caproic, isovaleric and particularly valeric acids in the rumen liquor. Moreover, the increases that occurred in the concentration of valeric acid as determined at hourly intervals in the rumen liquor of sheep given lucerne hay were of the same magnitude as the decreases that occurred in the molar concentration of proline, alanine and valine taken together. There was an obvious lag between the appearance of the peak concentrations of these amino acids and of valeric acid (see Figs. 2 and 4).

It was suggested by el-Shazly (1952) that proline and alanine may give valeric acid by a multiple-stage deaminative process, in which the Stickland (1934) reaction is one of the stages, and this suggestion was supported by Johnson, Dehority, Bentley \& Moxon (1957) and Dehority, Johnson, Bentley \& Moxon (1958).

Various authors have pointed to the metabolic importance of valeric acid and other medium-chain fatty acids in enhancing bacterial growth or cellulolytic activity (Bentley, Lehmkuhl, Johnson, Hershberger \& Moxon, 1954; Bryant \& Doetsch, 1955; Dehority, el-Shazly \& Johnson, I960; Dehority, Bentley, Johnson \& Moxon, 1957). These fatty acids are thought to be formed mainly by deamination of valine, proline and leucine.

The higher concentrations of propionic and butyric acids in the rumen liquor of sheep given lucerne hay, which possibly suggest a greater energetic efficiency of the lucerne hay ration (Blaxter, I 967 ), may be due to the higher pentosan content of this ration and to a lesser extent to deaminative processes.

As to which factors are responsible for the better utilization of lucerne hay $\mathrm{N}$ in the rumen, it may be stated that neither of the two $\mathrm{N}$ sources examined differ markedly either in their amino acid composition or in their solubility in artificial saliva (Table 4). Thus the degree of solubility, which with other feeds has been recognized as the main factor determining the different efficiencies of various proteins such as those of toasted and non-toasted oilseed meals (Chalmers \& Synge, I954; Tagari et al. 1962; Chalmers et al. 1964), does not appear to play an important part in this instance. However, the great difference in the concentrations of NPN, which formed $25.5 \%$ of the total N content of lucerne hay and only I. $5 \%$ of that of SBM, may have contributed to the difference in susceptibility of the two sources of nitrogenous substances to the action of rumen micro-organisms. A considerable part of the NPN present in lucerne hay consists of free amino acids; this NPN fraction is particularly high in proline, alanine, valine and serine, which rapidly disappear from rumen liquor in vivo. Further, the importance of the NPN fraction has been pointed out by earlier investigators (Gilroy, 1958; Bryant et al. 1958). According to their findings the NPN fraction of feeds can stimulate the metabolic activity of rumen micro-organisms and lead to an increase in protein synthesis. 
This investigation was supported by United States Department of Agriculture Grant No. FG-Is-205.

I thank Professor A. Bondi for encouragement and helpful discussions during the course of the work. I am grateful also to Mr M. A. Katz for his helpful advice in gaschromatography analysis.

\section{REFERENCES}

Abou Akkada, A. R. \& el-Sayed Osman, H. (1967). F. agric. Sci., Camb. 69, 25.

Annison, E. F. (1956). Biochem. F. 64, 705.

Bentley, O. G., Lehmkuhl, A., Johnson, R. R., Hershberger, T. V. \& Moxon, A. L. (I954). F. Am. chem. Soc. 76, 5000.

Blaxter, K. L. (1967). The Energy Metabolism of Ruminants, and ed. London: Hutchinson.

Block, R. I. \& Weiss, K. W. (1956). Amino Acid Handbook, pp. 306, 320. Springfield, Ill.: Charles C. Thomas.

Bondi, A. \& Neumark, H. (1960). Agriculture Yearbook, p. 249. (In Hebrew.) Tel-Aviv: Hassadeh Publishing Corp.

Bryant, M. P. \& Doetsch, R. N. (1955). F. Dairy Sci. 38, 340.

Bryant, M. P., Small, N., Bouma, C. \& Chu, H. (1958). F. Bact. 76, 15.

Chalmers, M. I., Jayasinghe, T. B. \& Marshall, B. M. (I964). F. agric. Sci, Camb. 63, 283.

Chalmers, M. I. \& Synge, R. L. M. (1954). F. agric. Sci., Camb. 44, 263.

Clarke, E. M. W., Ellinger, G. M. \& Phillipson, A. T. (1966). Proc. R. Soc. B 166, 69.

Conway, E. J. (I957). Microdiffusion Analysis and Volumetric Error, $4^{\text {th }}$ ed. London: Crosby Lockwood \& Son.

Dehority, B. A., Bentley, O. G., Johnson, R. R. \& Moxon, A. L. (1957). J. Anim. Sci. 16, 502.

Dehority, B. A., Johnson, R. R., Bentley, O. G. \& Moxon, A. L. (1958). Archs Biochem. Biophys. 78 , 5.

Dehority, B. A., el-Shazly, K. \& Johnson, R. R. (1960). F. Anim. Sci. 19, 1098.

El-Shazly, K. (1952). Biochem. F. 51, 640, 647 .

Erwin, E. S., Marco, G. J. \& Emery, E. M. (1961). F. Dairy Sci, 44, 1768.

Fontenot, J. P., Gallup, W. D. \& Nelson, A. B. (1955). F. Anim. Sci. 14, 807.

Forbes, R. M. \& Garrigus, W. P. (1949). F. agric. Res. 78, 483.

Gilroy, J. R. (1958). Nitrogen requirement for growth of bovine rumen bacteria. PhD Thesis, Maryland University, USA.

Guggolz, I., Herring, V. V. \& Kohler, G. O. (1967). F. agric. Fd Chem. 15, 1052.

Henderickx, H. \& Martin, J. (1963). In vitro Study of the Nitrogen Metabolism in the Rumen. Gent: State Agriculture College, Department of Animal Nutrition and Animal Husbandry.

Houpt, T. R. (1959). Am. F. Physiol. 197, 115.

Johnson, R. R., Dehority, B. A., Bentley, O. G. \& Moxon, A. L. (1957). Fedn Proc. Fedn Am. Socs exp. Biol. 16, 202.

Lewis, D. (1957). F. agric. Sci., Camb. $48,438$.

McDonald, I. W. (r948). Biochem. F. 42, 584 .

Mitchell, H. H. (1943). F. Anim. Sci. 2, 263.

Moir, R. J. \& Somers, M. (1957). Aust. F. agric. Res. 8, 253.

Packett, L. V. \& McCune, R. W. (1965). Appl. Microbiol. 13, 22.

Sherrod, L. B. \& Tillman, A. D. (rg62). J. Anim. Sci. 21, 901.

Stickland, L. H. (1934). Biochem. $\mathcal{F} .28$, 1746.

Tagari, H., Ascarelli, I. \& Bondi, A. (I962). Br. F. Nutr. 16, 237

Tagari, H., Dror, Y., Ascarelli, I. \& Bondi, A. (I 964). Br. F. Nutr. 18, 333.

Tagari, H., Krol, O. \& Bondi, A. (1965). Nature, Lond. 206, 37. 